\title{
Nuclides Composition of Experimental Power Reactor (RDE) Spent Fuel
}

\author{
Kristina $^{1 *}$, Amir Hamzah ${ }^{2}$, Muhammad Subekti ${ }^{2}$, and Menik Ariani ${ }^{1}$ \\ ${ }^{1}$ Sriwijaya University, Jl. Raya Palembang-Prabumulih KM.32, Indralaya, OganIlir, 30662, Indonesia \\ ${ }^{2}$ Center for Nuclear Reactor Technology and Safety - BATAN, Puspitek Area, Building No.80, Serpong, Tanggerang Selatan, 15310, Indonesia
}

\section{ARTICLE INFO}

\section{Article history:}

Received: 7 February 2020

Received in revised form: 24 February 2020

Accepted: 25 February 2020

\section{Keywords:}

Nuclides composition

Pebble

Spent fuel

$\mathrm{RDE}$

MCNPX

\begin{abstract}
A B S T R A C T
The management of spent fuel is an issue of safety for Indonesia in the phase of designing RDE. Several studies regarding spent fuel are limited by geometrical characteristics and number of nuclides library. Therefore, different methodologies utilizing MCNPX2.6.0 were applied to get better information for further research. In this study, a single fuel pebble containing $\mathrm{UO}_{2}$ was burned using 5 cycles of multi-pass loading scheme for 1080 days to obtain the same energy as RDE's core, which is about $79.90 \mathrm{GWd} / \mathrm{MTU}$. The multiplication factor $k$-inf decreased at each cycle and stopped at 1.14575. Afterwards, the fuel was decayed for 5 years as a representation of cooling time in the spent fuel storage tank. The calculation results in the nuclides composition of the spent fuel after 1080 days of burning and 5 years of cooling containing 241 nuclides, which consist of 21 actinides and 220 nonactinides. Actinides with the highest activity of $8.96 \mathrm{Ci}$ is ${ }_{94}^{241} \mathrm{Pu}$ with mass of $0.0867 \mathrm{~g}$, whose halflife time is 14 years long. Nonactinides with the highest activity of 4.47 $\mathrm{Ci}$ is ${ }_{55}^{137} \mathrm{Cs}$ with mass of $0.0514 \mathrm{~g}$, whose half-life time is 30.17 years long. The total activity of spent fuel pebble is $22.9 \mathrm{Ci}$ with total mass of $5.28 \mathrm{~g}$. The mass and activity data of each nuclides contained in the spent pebble will be used in the future research for performing safety analysis of the spent fuel storage tank.
\end{abstract}

\section{INTRODUCTION}

Experimental Power Reactor (Reaktor Daya Eksperimental, RDE) is an Indonesia nuclear reactor project that aim to demonstrate a safe and reliable electricity production [1]. National Nuclear Energy Agency of Indonesia (BATAN) has been carrying out some basic research for designing RDE since 2010. Furthermore, the document of basic engineering design was completed at 2017 while the completion of detail engineering design document is still on progress. The project proposed that hopefully by 2023 the RDE will start its operation [2]. RDE was inspired by the research

"Corresponding author. Tel./Fax.: +6281382287964

E-mail: kristinazhang@student.unsri.ac.id DOI: $10.17146 / \mathrm{tdm} .2020 .22 .1 .5787$ and development program for the HighTemperature Gas-cooled Reactor (HTGR) to develop HTR-10, the 10 MWth reactor which was launched at Institute of Nuclear and New Energy Technology (INET), Tsinghua University in China about 28 years ago [1,3-5]. According to the safety demonstration test, HTR-10 had inherent safety features and was recognized as a representative advanced nuclear system for the future [6]. Aside from that, HTR-10 is one of the generation-IV nuclear reactors. On account of this reason, RDE is expected to solve the problem of electricity supply in Indonesia [3].

Inherent safety of nuclear power plant has gotten thoroughly attention after the nuclear accident at Fukushima in Japan. Together with the reactor itself, the spent fuel storage system also has 
to possess inherent safety features [7]. Moreover, the key issues of safety for nuclear reactor, which are reported by the nuclear energy agency (NEA), rely heavily on the management of spent fuel [8]. Generally, spent fuel is considered as a waste but in certain circumstances it is also considered as a potential future energy resource. The management of spent fuel for both definitions must include a spent fuel storage system management [9-10]. The reason behind this management is purely to minimize the risk of radiation by making it is isolated to human and the environment for as long as it is still hazardous [11]. The management of spent fuel has also become a safety issue for Indonesia in the phase of designing RDE. Thus, the study of spent fuel storage shall be discussed in several aspects including neutronic aspect. The basic requirement for studying spent fuel storage is the specific information of nuclides contained in the spent fuel. Therefore, an analysis of nuclides composition in spent fuel is essential.

Various studies have been conducted to investigate nuclides in spent fuel [3-4]. They relied merely on ORIGEN2.1 code to characterize the radionuclides of RDE's spent fuel. The calculation of ORIGEN2.1 can be done in a fast computation time. However, it is limited by one-dimensional of geometrical characteristics along with the numbers of nuclide library that can be handled for about 1,700 nuclides [4, 12-14]. Moreover, in order to get accurate result using ORIGEN2.1, the one-group cross section of the nuclides should be weighted by the neutron flux of the reactor [13-14]. Due to this limitation, CINDER90 code was proposed. CINDER90 can handle three-dimensional of geometry effects and consists of the double amounts of nuclides as in ORIGEN2.1. According to Sung-Min and Myung in 2014, CINDER90 gave the best performance when compared to ORIGEN2.1 [12]. As a coupled code of MCNP with CINDER90, MCNPX2.6.0 has been used in this study to get more reliable and accurate result in characterizing the nuclides of RDE's spent fuel.

\section{THEORY}

\section{RDE Fuel Description}

The fuel of RDE is exactly the same as the fuel of HTR-10 which is a fuel pebble with TRISO coated particles. Fig. 1 shows the construction of the fuel pebble and the TRISO fuel particles embedded in the fuel zone matrix of the fuel pebble. The kernel of the particle is composed of the fissile material, $\mathrm{UO}_{2}$. A porous carbon buffer zone is designed to provide space for fission-product gases, immediately surrounds the kernel. Moreover, a dense carbon zone, the inner pyrolytic carbon (iPyC) layer, provides a diffusion barrier for the fission products. This is followed by a layer of silicon carbide ( $\mathrm{SiC})$, which supplies most of the fuel particle's strength. Finally, an outer pyrolytic carbon (oPyC) layer protects the $\mathrm{SiC}$ layer and provides a further impediment to diffusion [15].

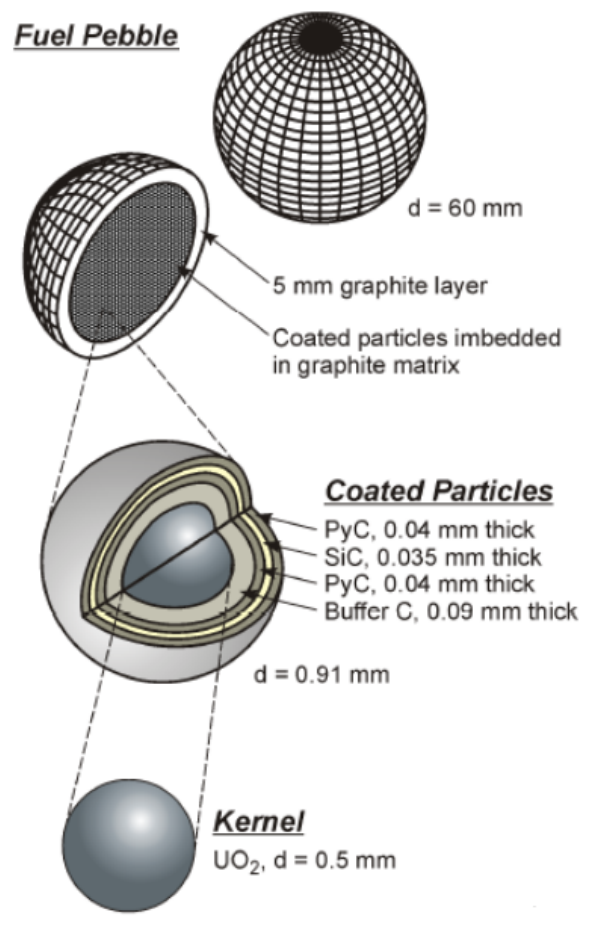

Fig. 1. The construction of the fuel pebble and the TRISO fuel particles embedded in the fuel zone matrix of the fuel pebble [15]

\section{Nuclear Criticality}

A stable fission chain reaction and a constant production rate of fission energy can be sustained by designing a nuclear reactor in such a way so that the rates of neutron absorption and leakage are balanced by the rate of fission neutron production. A given neutron will be born in a fission event and then usually scatter until its eventual death in either an absorption reaction or by leaking out. Certain number of neutrons will be absorbed by fissile or fissionable nuclei and include further fission, hence leading to the birth of new fission neutrons. The ratio of new neutron produced to given neutron is known as multiplication factor $k$ [16]:

$$
k=\frac{\text { Number of neutrons in one generation }}{\text { Number of neutron in preceding generation }}
$$

The value of $k$ is categorized into three kinds, which can be seen in Fig. 2. 


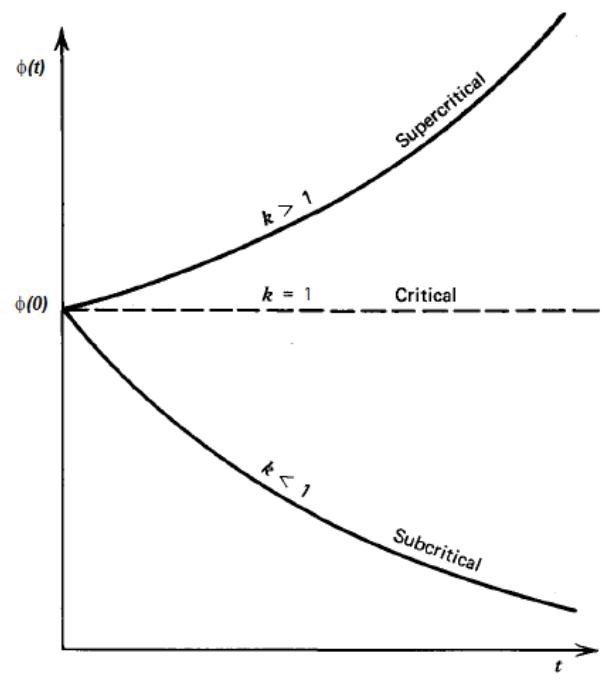

Fig. 2. Three kinds of multiplication factor $k$ based on neutron's number from time to time [16]

\section{Burnup Calculation}

The nuclear reactor analysis depends greatly on computer codes to identify the reactor performance. Neutronic analysis of a reactor is frequently done with deterministic or stochastic methods. Deterministic method solves the transport equation for the average particle behavior while stochastic method models individual particles and recording their behavior [17]. The Monte Carlo method directly simulates neutron transport as a stochastic process [18-19].

MCNPX is the next generation in the series of Monte Carlo transport codes that began at Los Alamos National Laboratory nearly sixty years ago [20-21]. It is a Fortran90 general-purpose Monte Carlo N-Particle code that has been developed as an extension of the MCNP (MCNP eXtended). In contrast to MCNP, MCNPX can concern all particles and all energies. More importantly, MCNPX 2.6.0 also covered the advancements in transmutation module and library tools through CINDER90. CINDER90 is used to calculate the inventory of nuclide in an irradiated material or more often called as a burnup code. It calculates the atomic density of each nuclide present at a specified time. As a unique transmutation code, CINDER90 has a library of 63-group cross sections that constantly growing in breadth and quality with international cooperation, describes 3400 nuclides, 1325 fission products, and yield sets for over 30 actinides in the range $1 \leq \mathrm{Z} \leq 103$ [12].

The rate of change in the atomic density $N_{m}$ is the sum of losses and gains in the nuclide $m$. The losses are from the radioactive decay of nuclide $m$, and transmutation from nuclide $m$ to other nuclides while the gains are from the productions of the nuclide itself. The atomic density differential equation used in CINDER90 is shown as [17, 22]:

$$
\begin{aligned}
& \begin{array}{l}
\frac{d N_{m}(t)}{d t}=-N_{m}(t) \beta_{m}+\bar{\gamma}_{m} \\
\quad+\sum_{k \neq m} N_{k}(t) \gamma_{k \rightarrow m}
\end{array} \\
& \beta_{m}=\lambda^{m}+\phi \sigma_{a}^{m} \\
& \gamma_{k \rightarrow m}=\sum_{m \neq k} L_{k m} \lambda_{k}+ \\
& \sum_{m \neq k} \sum_{j} \int \gamma_{k m, j}(E) \sigma_{k, j}(E) \phi(r, E, t) d E
\end{aligned}
$$

where $\beta_{m}$ is the total transmutation probability of nuclide $m, \lambda_{m}$ is the total decay constant of nuclide $m, \phi$ is the energy integrated neutron flux, $\sigma_{a}^{m}$ is the flux weighted average cross section for neutron absorption by nuclide $m$, and $\gamma_{k \rightarrow m}$ is the probability of nuclide $k$ transmuting by decay or absorption to nuclide $m$.

The set of differential equations describing all nuclides are coupled because each equation is interrelated and contains atomic density information of other nuclides. This set of coupled differential equations is reduced to a set of independent, linear differential equations using the Markov Chains method [17, 22] shown below:

$\frac{d N_{i}}{d t}=\bar{Y}_{\imath}+N_{i-1}(t) \gamma_{i-1}-N_{i}(t) \beta_{i}$

The solutions of each linear chain determine a partial nuclide density $[15,20]$ as follows:

$$
\begin{aligned}
& N_{n}(t)=\sum_{m=1}^{n} \prod_{k=m}^{n-1} \gamma_{k}\left\{\overline { Y _ { m } } \left[\frac{1}{\prod_{l=m}^{n} \beta_{l}}-\right.\right. \\
& \left.\left.\sum_{j=m}^{n} \frac{e^{-\beta_{j t}}}{\prod_{i=m, \neq j}^{n}\left(\beta_{i}-\beta_{j}\right)}\right]+N_{m}^{0} \sum_{j=m}^{n} \frac{e^{-\beta_{j t}}}{\prod_{i=m, \neq j}^{n}\left(\beta_{i}-\beta_{j}\right)}\right\}
\end{aligned}
$$

Partial nuclide densities are then summed to determine the total nuclide density. Each path for each nuclide is defined by the available data.

\section{METHODOLOGY}

The calculation to predict the nuclides composition of RDE's spent fuel was carried out by using MCNPX2.6.0 code with ENDF/B-VI nuclear data library. The calculation required a fuel pebble modeling illustrated in Fig. 1. Some studies related to fuel pebble modeling have been done where different kinds of TRISO lattice did not give significant impacts to the burnup performance [21, 23]. In addition to that, a comparison regarding TRISO arrangement in the fuel pebble has been studied where the Auto-filled TRISO in Pebble (ATIP) gave nearly the same result as Organized TRISO in Pebble (OTIP) [5]. Due to this reason, a simple cubic (SC) lattice with ATIP model was used to get an efficient modeling.

The modeling of fuel pebble can be performed through visual editor application presented by MCNP, or by making its own input code using a text editor application. The input code composed of cell card, surface card and data card. The cell card 
holds information about part of the fuel that is bounded by surface described on the surface card as well as the type of material used, material density, cell volume, and the type of particles tracked within those cells. The data card holds specific information about the material used in the previous cell card and type of calculation that user requires MCNP to calculate [21], where in this case is burnup calculation. To get an abundant number of the resulted nuclides in the burnup calculation, Tier 3 parameter was used, given that it comprises plenty of fission products content which have CINDER90 yield information. Apart from that, the threshold of atomic fraction was set from 1.0E-10 to $1.0 \mathrm{E}-20$ so that more nuclides with smaller atomic fraction will be processed in the burnup calculation.
The burnup scenario used in this research is only for a single fuel pebble. Since the RDE's core contains 27000 pebbles that will be burned for 1080 days with $10 \mathrm{MW}$ power to obtain energy of 80 $\mathrm{GWd} / \mathrm{MTU}$, then a single fuel pebble will be burned for 1080 days with $370 \mathrm{~W}$ power to obtain the same energy. Using 5 cycles in the multi-pass loading scheme, a pebble will be burned for 216 days in each cycle. Considering that a pebble will be waiting for its turn in the discharge tube for 40 days [4], then the decay period will also be added at the end of each cycle. Furthermore, another 5 years of decay process will be added as a representation of cooling time in the spent fuel storage tank. The specification of the fuel pebble is explained in Table 1 while the material composition of fuel pebble is defined in Table 2.

Table 1. Specification of fuel pebble

\begin{aligned} & \hline Parameters Values \\ & \hline Density of graphite in matrix and outer shell $1.73 \mathrm{~g} / \mathrm{cm} 3 \\ &$ Heavy metal (uranium) loading (weight) $5.0 \mathrm{~g} \\ &$ Uranium enrichment (U-235 / total U by weight) $17 \% \\ &$ UO2 density $10.4 \mathrm{~g} / \mathrm{cm} 3 \\ &$ Coating layer materials (starting from kernel) Buffer/PyC/SiC/PyC \\ & Coating layer densities (g/cm3), respectively $1.1 / 1.9 / 3.18 / 1.9 \\ &$ Number of TRISO coated particles 8335 \\ & Thermal energy $3.64628 \mathrm{E}-08 \mathrm{MeV} \\ &$\hline\end{aligned}

Table 2. Material composition of fuel pebble

\begin{tabular}{cc}
\hline Nuclides & Weight $(g)$ \\
\hline${ }_{92}^{235} U$ & 0.85 \\
${ }_{92}^{238} U$ & 4.15 \\
${ }_{92}^{16} \mathrm{O}$ & 0.6734 \\
${ }_{8} \mathrm{O}$ & 194.709 \\
${ }_{6} \mathrm{C}$ & 0.5521 \\
${ }_{14} 8 i$ & 200.9345 \\
Total & \\
\hline
\end{tabular}

\section{RESULTS AND DISCUSSION}

The modeling of fuel pebble using MCNPX2.6.0 visual editor can be seen in Fig. 3. It appears that the model already satisfied the construction of fuel pebble required for RDE which is illustrated in Fig. 1. Based on the model, the energy result from burnup process is 79.90 GWd/MTU which approximately equal to the energy of RDE's core. The calculation performed in the fuel pebble is using a reflective boundary condition, hence the multiplication factor value obtained is the $k$-inf. The criticality condition of fuel pebble in Fig. 4 shows that $k$-inf decreased at each cycle. This happened because at each burnup process, neutron will be used in a fission event and also will be produced which then usually scatter until it meets its eventual death in either an absorption reaction or by leaking out. Since the boundary of fuel pebble is reflective, there is no neutron leaks out from the system. That's why even after 1080 days of burning, the multiplication factor value still shows a supercritical condition which is about 1.14575. The k-eff value of spent fuel in the storage tank should be in a subcritical condition. Since the value of $k$-inf did not consider the leakage of neutron from the system thus the value of $k$-eff will be much smaller than $k$-inf. The value of $k$-eff can be calculated by multiplying the $k$-inf value with the non-leakage probability. 


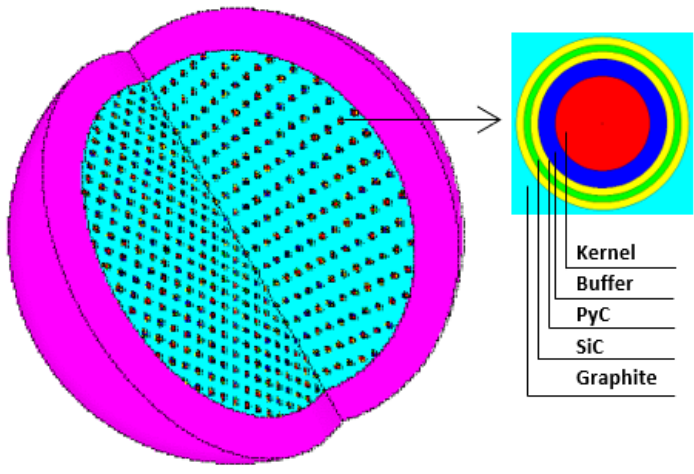

Fig. 3. Fuel pebble model using MCNPX Visual Editor.

The initial composition of fuel pebble only contains $5.6734 \mathrm{~g}$ of $\mathrm{UO}_{2}$ with $0.85 \mathrm{~g}$ of ${ }_{92}^{235} \mathrm{U}, 4.15$ $\mathrm{g}$ of ${ }_{92}^{238} U$, and $0.6734 \mathrm{~g}$ of ${ }_{8}^{16} O$. After 1080 days of burning and 5 years of cooling the fuel turns into spent fuel. The spent fuel contains 241 nuclides that could be defined as 21 actinides and 220 nonactinides. Actinides and Nonactinides inventory after 5 years of cooling can be seen in Table 3. Due

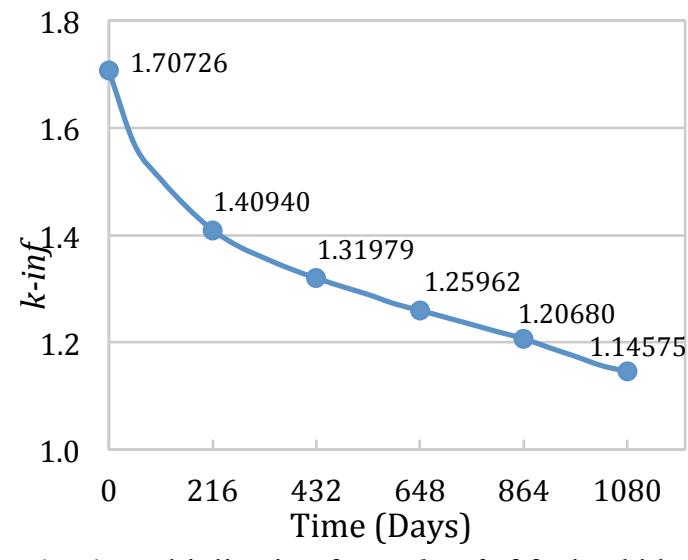

Fig. 4. Multiplication factor $k$-inf of fuel pebble at each step of burning and cooling.

to the excessive numbers of nonactinides especially the fission products, the data shown in the table is only the nuclides whose activity is higher than 1.0E-10 Ci. All nuclides obtained are basically originated from the fuel itself, $\mathrm{UO}_{2}$, especially the product of fission. Mostly they have medium-tolong half-life because they still existed even after 5 years of cooling.

Table 3. Nuclides composition of spent fuel after 5 years of cooling

\begin{tabular}{|c|c|c|c|c|c|c|c|c|}
\hline Nuclides & Mass $(\mathrm{g})$ & Activity $(\mathrm{Ci})$ & Nuclides & Mass $(\mathrm{g})$ & Activity (Ci) & Nuclides & Mass (g) & Activity $(\mathrm{Ci})$ \\
\hline \multicolumn{9}{|c|}{ Actinides Inventory } \\
\hline${ }_{90}^{231} T h$ & $5.63 \mathrm{E}-13$ & 2.99E-07 & ${ }_{92}^{237} U$ & 2.63E-09 & $2.14 \mathrm{E}-04$ & ${ }_{93}^{239} \mathrm{~Np}$ & $3.03 \mathrm{E}-08$ & 7.02E-03 \\
\hline${ }_{90}^{232} \mathrm{Th}$ & $2.23 \mathrm{E}-08$ & $2.44 \mathrm{E}-15$ & ${ }_{92}^{238} U$ & $2.38 \mathrm{E}+00$ & $8.00 \mathrm{E}-07$ & ${ }_{94}^{236} \mathrm{Pu}$ & $1.74 \mathrm{E}-11$ & $9.09 \mathrm{E}-09$ \\
\hline${ }_{90}^{234} \mathrm{Th}$ & $3.46 \mathrm{E}-11$ & $8.00 \mathrm{E}-07$ & ${ }_{92}^{240} U$ & $3.62 \mathrm{E}-17$ & 3.35E-11 & ${ }_{94}^{238} \mathrm{Pu}$ & $5.04 \mathrm{E}-03$ & $8.63 \mathrm{E}-02$ \\
\hline${ }_{91}^{233} \mathrm{~Pa}$ & $4.61 \mathrm{E}-10$ & $9.57 \mathrm{E}-06$ & ${ }_{93}^{235} \mathrm{~Np}$ & $1.34 \mathrm{E}-13$ & $1.88 \mathrm{E}-10$ & ${ }_{94}^{239} \mathrm{Pu}$ & $2.37 \mathrm{E}-01$ & $1.47 \mathrm{E}-02$ \\
\hline${ }_{92}^{234} U$ & $2.24 \mathrm{E}-04$ & $1.39 \mathrm{E}-06$ & ${ }_{93}^{236} \mathrm{~Np}$ & 2.61E-09 & $3.44 \mathrm{E}-11$ & ${ }_{94}^{240} \mathrm{Pu}$ & $4.01 \mathrm{E}-02$ & $9.10 \mathrm{E}-03$ \\
\hline${ }_{92}^{235} \mathrm{U}$ & $1.38 \mathrm{E}-01$ & 2.99E-07 & ${ }_{93}^{237} \mathrm{~Np}$ & $1.36 \mathrm{E}-02$ & $9.57 \mathrm{E}-06$ & ${ }_{94}^{241} \mathrm{Pu}$ & $8.67 \mathrm{E}-02$ & $8.96 \mathrm{E}+00$ \\
\hline${ }_{92}^{236} U$ & $1.03 \mathrm{E}-01$ & $6.66 \mathrm{E}-06$ & ${ }_{93}^{238} \mathrm{~Np}$ & $8.48 \mathrm{E}-12$ & $2.20 \mathrm{E}-06$ & ${ }_{94}^{242} \mathrm{Pu}$ & $6.64 \mathrm{E}-02$ & $2.63 \mathrm{E}-04$ \\
\hline \multicolumn{9}{|c|}{ Nonactinides Inventory } \\
\hline${ }_{6}^{14} \mathrm{C}$ & $5.33 \mathrm{E}-10$ & 2.37E-09 & ${ }_{46}^{107} \mathrm{Pd}$ & $1.42 \mathrm{E}-02$ & $7.30 \mathrm{E}-06$ & 袮 $\mathrm{Ba}$ & $2.19 \mathrm{E}-11$ & 5.61E-09 \\
\hline${ }_{34}^{79} \mathrm{Se}$ & $1.93 \mathrm{E}-04$ & $2.65 \mathrm{E}-05$ & ${ }_{47}^{111} \mathrm{Ag}$ & $6.13 \mathrm{E}-14$ & $9.68 \mathrm{E}-09$ & ${ }_{56}^{140} B a$ & $2.84 \mathrm{E}-13$ & $2.08 \mathrm{E}-08$ \\
\hline${ }_{36}^{85} \mathrm{Kr}$ & $6.08 \mathrm{E}-04$ & $2.39 \mathrm{E}-01$ & ${ }_{50}^{123} \mathrm{Sn}$ & 4.73E-10 & $3.89 \mathrm{E}-06$ & ${ }_{57}^{140} \mathrm{La}$ & $3.74 \mathrm{E}-14$ & $2.08 \mathrm{E}-08$ \\
\hline${ }_{38}^{89} \mathrm{Sr}$ & $9.08 \mathrm{E}-14$ & 2.64E-09 & ${ }_{50}^{126} S n$ & $1.25 \mathrm{E}-03$ & $3.54 \mathrm{E}-05$ & ${ }_{58}^{141} \mathrm{Ce}$ & $6.73 \mathrm{E}-13$ & $1.92 \mathrm{E}-08$ \\
\hline${ }_{38}^{90} \mathrm{Sr}$ & $1.67 \mathrm{E}-02$ & $2.35 \mathrm{E}+00$ & ${ }_{51}^{125} \mathrm{Sb}$ & $1.24 \mathrm{E}-04$ & $1.30 \mathrm{E}-01$ & ${ }_{58}^{143} \mathrm{Ce}$ & 2.05E-14 & $1.36 \mathrm{E}-08$ \\
\hline${ }_{39}^{90} \mathrm{Y}$ & 4.33E-06 & $2.35 \mathrm{E}+00$ & ${ }_{51}^{126} S b$ & $5.92 \mathrm{E}-11$ & $4.95 \mathrm{E}-06$ & ${ }_{58}^{144} \mathrm{Ce}$ & $1.29 \mathrm{E}-04$ & $4.12 \mathrm{E}-01$ \\
\hline${ }_{39}^{11} Y$ & $4.30 \mathrm{E}-13$ & $1.06 \mathrm{E}-08$ & ${ }_{52}^{132} \mathrm{Te}$ & $4.55 \mathrm{E}-14$ & $1.38 \mathrm{E}-08$ & ${ }_{59}^{143} \mathrm{Pr}$ & $2.03 \mathrm{E}-13$ & $1.36 \mathrm{E}-08$ \\
\hline${ }_{40}^{93} \mathrm{Zr}$ & 2.71E-02 & $6.82 \mathrm{E}-05$ & ${ }_{53}^{129} I$ & $9.51 \mathrm{E}-03$ & $1.68 \mathrm{E}-06$ & ${ }_{59}^{145} \mathrm{Pr}$ & $2.90 \mathrm{E}-15$ & $1.05 \mathrm{E}-08$ \\
\hline${ }_{40}^{95} \mathrm{Zr}$ & $3.78 \mathrm{E}-12$ & $8.12 \mathrm{E}-08$ & ${ }_{53}^{131} I$ & $8.24 \mathrm{E}-14$ & $1.02 \mathrm{E}-08$ & ${ }_{60}^{147} \mathrm{Nd}$ & $8.35 \mathrm{E}-14$ & $6.76 \mathrm{E}-09$ \\
\hline${ }_{41}^{94} \mathrm{Nb}$ & $6.25 \mathrm{E}-08$ & $1.17 \mathrm{E}-08$ & ${ }_{53}^{132} I$ & $1.37 \mathrm{E}-15$ & $1.42 \mathrm{E}-08$ & ${ }_{61}^{147} \mathrm{Pm}$ & $1.81 \mathrm{E}-03$ & $1.68 \mathrm{E}+00$ \\
\hline${ }_{41}^{95} \mathrm{Nb}$ & $4.38 \mathrm{E}-12$ & $1.72 \mathrm{E}-07$ & ${ }_{53}^{133} I$ & $1.69 \mathrm{E}-14$ & $1.92 \mathrm{E}-08$ & ${ }_{61}^{149} \mathrm{Pm}$ & $1.25 \mathrm{E}-14$ & 4.94E-09 \\
\hline${ }_{41}^{97} \mathrm{Nb}$ & $3.91 \mathrm{E}-16$ & $1.05 \mathrm{E}-08$ & $\begin{array}{c}134 \\
{ }_{53} I\end{array}$ & $8.42 \mathrm{E}-16$ & $2.25 \mathrm{E}-08$ & ${ }_{61}^{151} \mathrm{Pm}$ & $3.25 \mathrm{E}-15$ & 2.38E-09 \\
\hline${ }_{42}^{99} \mathrm{Mo}$ & $2.77 \mathrm{E}-14$ & $1.33 \mathrm{E}-08$ & ${ }_{53}^{135} I$ & $6.26 \mathrm{E}-15$ & $2.21 \mathrm{E}-08$ & ${ }_{62}^{151} \mathrm{Sm}$ & 3.69E-04 & $9.71 \mathrm{E}-03$ \\
\hline${ }_{43}^{99} \mathrm{Tc}$ & $3.17 \mathrm{E}-02$ & 5.43E-04 & ${ }_{54}^{133} \mathrm{Xe}$ & $1.03 \mathrm{E}-13$ & $1.93 \mathrm{E}-08$ & ${ }_{63}^{152} E u$ & $2.47 \mathrm{E}-07$ & $4.35 \mathrm{E}-05$ \\
\hline${ }_{44}^{103} R u$ & 7.33E-13 & $2.37 \mathrm{E}-08$ & ${ }_{54}^{135} \mathrm{Xe}$ & $9.99 \mathrm{E}-15$ & $2.54 \mathrm{E}-08$ & ${ }_{63}^{154} E u$ & $6.61 \mathrm{E}-04$ & $1.79 \mathrm{E}-01$ \\
\hline${ }_{44}^{105} R u$ & $4.68 \mathrm{E}-15$ & $3.15 \mathrm{E}-08$ & ${ }_{55}^{134} \mathrm{Cs}$ & $8.18 \mathrm{E}-04$ & $1.06 \mathrm{E}+00$ & ${ }_{63}^{155} E u$ & $1.48 \mathrm{E}-04$ & $7.30 \mathrm{E}-02$ \\
\hline${ }_{44}^{106} R u$ & 2.51E-04 & $8.32 \mathrm{E}-01$ & ${ }_{55}^{135} \mathrm{Cs}$ & $1.53 \mathrm{E}-02$ & $1.76 \mathrm{E}-05$ & ${ }_{64}^{153} G d$ & $1.17 \mathrm{E}-10$ & 4.15E-07 \\
\hline \multirow{2}{*}{${ }_{45}^{105} R h$} & 3.73E-14 & $3.15 \mathrm{E}-08$ & ${ }_{55}^{137} \mathrm{Cs}$ & 5.14E-02 & $4.47 \mathrm{E}+00$ & Etc. & $2.04 \mathrm{E}+00$ & $5.04 \mathrm{E}-09$ \\
\hline & & & & & & Total & $5.28 \mathrm{E}+00$ & $2.29 \mathrm{E}+01$ \\
\hline
\end{tabular}


Within all the actinides, ${ }_{94}^{241} \mathrm{Pu}$, whose halflife is 14 years, has the highest activity of $8.96 \mathrm{Ci}$ with mass of 0.0867 g. ${ }_{94}^{241} P u$ is formed when ${ }_{94}^{240} \mathrm{Pu}$ captures a neutron, which is yet opposite to ${ }_{94}^{240} \mathrm{Pu},{ }_{94}^{241} \mathrm{Pu}$ is a fissile material. Among all the nonactinides, ${ }_{55}^{137} \mathrm{Cs}$, whose half-life is 30.17 years, has the highest activity of $4.47 \mathrm{Ci}$ with mass of 0.0514 g. ${ }_{38}^{90} \mathrm{Sr}$ and ${ }_{39}^{90} \mathrm{Y}$ have the same activity of $2.35 \mathrm{Ci}$ which make them the $2^{\text {nd }}$ highest activity after ${ }_{55}^{137} C s$. Those 3 actinides are the fission products that have vital consequences to human health. Alongside with ${ }_{55}^{137} \mathrm{Cs},{ }_{38}^{90} \mathrm{Sr}$ becomes a huge concern with its slightly long half-life, which is precisely 28.79 years. Activities history from the top-8 highest nuclides activity after 5 years of cooling is shown in Fig. 5.

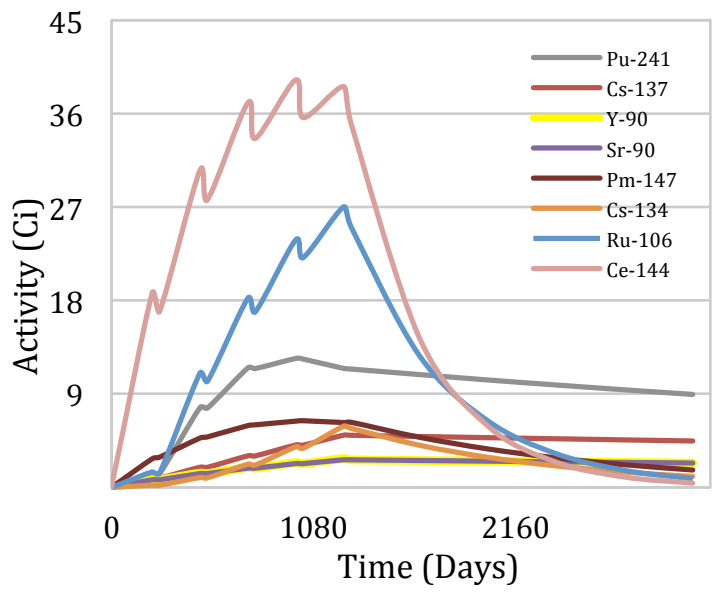

Fig. 5. Top-8 highest activity after 5 years of cooling.

Most of the nuclides shown in Fig. 5 have a fluctuated activity in the burning period and a constant activity at the end of cooling period. The fluctuated activity is occurred due to the additional 40 days of decay processes at the end of each cycle. The zig-zagged curve was formed because the activity went up when the burning process happened and went down when the cooling process happened. The burning period increased the nuclides activity as a result of the production of the nuclides itself while the cooling period decreased the nuclides activity as a result of the decay processes. The increment and decrement mostly caused by the gains and losses in the nuclide density explained in eq. 2 . Nuclide with the shortest half-time will has the greatest activity decrement in the decay period. ${ }_{39}^{90} Y$ has the shortest half-time among the other 7 nuclides shown in the graph which is about 64.60 hours. However, since it has a rather small activity then the decrement is also small. The greatest decrement can be seen in ${ }_{58}^{144} \mathrm{Ce}$ followed by ${ }_{44}^{106} R u$ which has the shortest half-life after ${ }_{39}^{90} Y$ which is about 284.91 days and 371.59 days respectively. Furthermore, the constant activity at the end of cooling period happened since the value of losses and gains of nuclides are remained the same.

Within all the nuclides there exist 7 long-lived fission products such are ${ }_{43}^{99} \mathrm{Tc},{ }_{50}^{126} \mathrm{Sn},{ }_{34}^{79} \mathrm{Se}$, with half-life of between 200-300 thousand years, and ${ }_{40}^{93} \mathrm{Zr},{ }_{55}^{135} \mathrm{Cs},{ }_{46}^{107} \mathrm{Pd},{ }_{53}^{129} \mathrm{I}$ with half-life of millions of years. Fortunately, those 7 nuclides have a rather small activity. However, some of them, especially ${ }_{43}^{99} \mathrm{TC}$ and ${ }_{53}^{129} \mathrm{I}$ have the greatest biohazards as well as neutron capture cross-section. The total activity of spent fuel pebble is $22.9 \mathrm{Ci}$ with total mass of 5.28 g. About 25 nonactinides have an activity below $1.0 \mathrm{E}-10 \mathrm{Ci}$ and 142 nonactinides have zero activity. Those 167 nuclides are isotopes of $\mathrm{Se}, \mathrm{Rb}$, $\mathrm{Y}, \mathrm{Cd}, \mathrm{In}, \mathrm{Sn}, \mathrm{Sb}, \mathrm{Te}, \mathrm{I}, \mathrm{Cs}, \mathrm{La}, \mathrm{Ce}, \mathrm{Nd}, \mathrm{Sm}, \mathrm{Eu}$, $\mathrm{Gd}, \mathrm{Tb}, \mathrm{Dy}$ and etc.

According to Husnayani and Udiyani in 2018, the total activity of RDE spent fuel after 5 years of cooling is $6.43 \mathrm{Ci}$ [3] which is quite small if compared to $22.9 \mathrm{Ci}$. The comparison of spent fuel activity at the end of burning and cooling period can be seen in Table 4. Overall, the calculation using MCNPX2.6.0 gave a higher activity compared to ORIGEN2.1. This is due to the different methodologies used in the computer code. As explained before, the nuclides discussed in this paper are the nuclides with activity higher than 1.0E-10 while the other one only for important nuclides or nuclides with activity higher than $1.0 \mathrm{E}-$ 05 . Moreover, the nuclear data library used for both studies was different. Based on the ORIGEN user's manual the nuclear data library used in ORIGEN2.1 is ENDF/B-IV [13-14] while the nuclear data library used in MCNPX2.6.0 is ENDF/B-VI. Therefore, some of nuclides in MCNPX2.6.0 weren't found in ORIGEN2.1 calculation.

In fact, there is not only one pebble contained in a reactor. There will be thousands of pebbles contained in the reactor core. In relation to the handling process of RDE spent fuel, there will not only contain one spent pebble with $22.9 \mathrm{Ci}$ activity, but there will be thousands of spent pebbles after reactor reach its criticality, which means that the total activity of spent fuel will be multiplied by the number of all spent pebbles. 
Table 4. Comparison of spent fuel activity using ORIGEN2.1. and MCNPX2.6.0.

\begin{tabular}{lccc}
\hline \multirow{2}{*}{ Time (Years) } & \multicolumn{2}{c}{ Activity (Ci) } \\
\cline { 3 - 4 } & & ORIGEN2.1 [3] & MCNPX2.6.0 \\
\hline Burning & \multirow{4}{*}{ Cooling } & $1.06 \mathrm{E}+02$ & $2.61 \mathrm{E}+02$ \\
& $1^{\text {st }}$ & $2.19 \mathrm{E}+01$ & $6.03 \mathrm{E}+01$ \\
& $2^{\text {nd }}$ & $1.31 \mathrm{E}+01$ & $4.02 \mathrm{E}+01$ \\
& $3^{\text {rd }}$ & $9.34 \mathrm{E}+00$ & $3.10 \mathrm{E}+01$ \\
& $4^{\text {th }}$ & $7.46 \mathrm{E}+00$ & $2.59 \mathrm{E}+01$ \\
& $5^{\text {th }}$ & $6.43 \mathrm{E}+00$ & $2.29 \mathrm{E}+01$ \\
\hline
\end{tabular}

\section{CONCLUSION}

The nuclides composition of RDE spent fuel has been analyzed by using MCNPX2.6.0 burnup code. At first the fuel material of $\mathrm{UO}_{2}$, was burned for 1080 days with $370 \mathrm{~W}$ power using 5 cycles of multi-pass loading scheme to obtain energy of $79.90 \mathrm{GWd} / \mathrm{MTU}$. After 5 years of cooling, the spent fuel contained 241 nuclides with 21 actinides and 220 nonactinides. Actinides with the highest activity of $8.96 \mathrm{Ci}$ is ${ }_{94}^{241} \mathrm{Pu}$, with mass of $0.0867 \mathrm{~g}$ whose half-life is 14 years. Nonactinides with the highest activity of $4.47 \mathrm{Ci}$ is ${ }_{55}^{137} \mathrm{Cs}$, with mass of $0.0514 \mathrm{~g}$ whose half-life is 30.17 years. The total activity of spent fuel pebble is $22.9 \mathrm{Ci}$ with total mass of $5.28 \mathrm{~g}$. All the mass and activity data from each nuclide obtained from this research can be used in future research for performing safety analysis of the spent fuel storage tank.

\section{ACKNOWLEDGMENT}

The author would like to thank the National Nuclear Energy Agency of Indonesia (BATAN), especially to the Center for Nuclear Reactor Technology and Safety (PTKRN), for the joint research opportunity on nuclear computation using MCNPX code. The authors also want to thank Dr. Pande Made Udiyani for technical discussion on radioactivity and its penetration in the environment. The research was funded by PTKRN-BATAN of 2019-2020 and Sriwijaya University of 2019 fiscal years.

\section{REFERENCES}

1. Hong L.P., Sembiring T.M., Arbie B., Subki I. Analysis of the optimum fuel composition for the Indonesian experimental power reactor (10 MWth Pebble-Bed HTGR). in: The $5^{\text {th }}$ International Conference on Advanced in Nuclear Sciences and Engineering, Bandung. 2015. pp. 1-4.

2. BATAN. Experimental Power Reactor [Accessed: 12 September 2019]. Available from: http://www.batan.go.id.
3. Husnayani I., Udiyani P.M. Radionuclide characteristics of RDE spent fuels. Tri Dasa Mega. 2018. 20(2):69-76.

4. Aisyah, Mirawaty, Saputra D.L.I., Setiawan R. Characteristization of radionuclides in spent fuel from experimental pebble-bed reactor (in Indonesian). Urania. 2019. 25(1):45-58.

5. Kristina, Subekti M. Analysis of nuclides composition of spent fuel of experimental power reactor (EPR) using MCNPX 2.6.0 (in Indonesian). Sigma Epsilon. 2018. 22(2):6370.

6. Wu Z., Yu S. HTGR projects in China. Nucl. Eng. and Tech. 2007. 39(2):103-110.

7. Wang J., Huang Y., Tang Y., Wu B. Natural safety analysis of the spent fuel residual heat removal in loading and storage process of HTR-10. Energy Procedia. 2013. 39:227-239.

8. NEA Spent Nuclear Fuel Assay Data for Isotopic Validation. State-of-the-art Report NEA / NSC / WPNCS / DOC (2011) 5. OECD Publishing; 2011.

9. University of Calgary. Spent Nuclear Fuel [Accessed: 21 September 2019]. Available from: https://energyeducation.ca.

10. IAEA Storage of Spent Nuclear Fuel. Safety Guide No. SSG-15. Vienna, Austria: International Atomic Energy Agency; 2012.

11. Hedin A. Spent Nuclear Fuel - How Dangerous Is It. Stockholm, Sweden: Swedish Nuclear Fuel and Waste Management Co; 1997.

12. Kim S., Kim M.H. A Study on MCNPXCINDER90 System for Activation Analysis. in: Transactions of the Korean Nuclear Society Autumn Meeting, Pyeongchang. 2014.

13. Croff, A.G. A User's Manual for the ORIGEN2 Computer Code. Springfield: Oak Ridge National Laboratory; 1980.

14. Oak Ridge National Laboratory. RSICC Computer Code Collection. Oak Ridge: Oak Ridge National Laboratory; 2008.

15. Terry W.K. Evaluation of The Initial Critical Configuration of the HTR-10 Pebble-Bed Reactor. Idaho: Idaho National laboratory; 2006.

16. Duderstadt J.J. Nuclear Reactor Analysis. Canada: John Wiley \& Sons; 1976.

17. Bratton I.J. Modeling and Validation of The Fuel Depletion and Burnup of The OSU Research Reactor Using MCNPX/ CINDER'90. Ohio: The Ohio State University; 2012.

18. Stacey W.M. Nuclear Reactor Physics. Canada: John Wiley \& Sons; 2001. 
19. Waltar A.E., Todd D.R., Tsvetkov P.V. Fast Spectrum Reactors. New York Dordrecht Heidelberg London:Springer-Verlag; 2012.

20. Pelowitz D.B. MCNPX ${ }^{T M}$ User's Manual Version 2.6.0. Los Alamos: Los Alamos National Laboratory; 2008.

21. Luthfi W., Setiadipura T., Zuhair, Suwoto, Bakhri S. Criticality and burnup study on different TRISO modeling of HTR Pebble. J. Phys. 2019. 1198:1-16.
22. Fensin M.L, Hendricks J.S., McKinney G.W. Monte Carlo Burnup Interactive Tutorial. Los Alamos: Los Alamos National Laboratory; 2009.

23. Zuhair. Study on HTR pebble-bed calculation using various model of kernel and pebble lattices (in Indonesian). Sains Dasar. 2012. 1(1):7-17. 